\title{
Yugoslav female partisans in World War II
}

Les femmes partisanes yougoslaves pendant la Seconde Guerre mondiale

\section{Ivana Pantelić}

\section{(2) OpenEdition}

\section{Journals}

Electronic version

URL: https://journals.openedition.org/ceb/3971

DOI: 10.4000/ceb.3971

ISSN: 2261-4184

\section{Publisher}

INALCO

\section{Printed version}

Number of pages: 239-250

ISBN: 978-2-85831-205-4

ISSN: 0290-7402

\section{Electronic reference}

Ivana Pantelić, "Yugoslav female partisans in World War II", Cahiers balkaniques [Online], $41 \mid 2013$,

Online since 19 May 2013, connection on 21 September 2021. URL: http://journals.openedition.org/ ceb/3971 ; DOI: https://doi.org/10.4000/ceb.3971

This text was automatically generated on 21 September 2021.

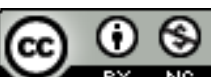

Cahiers balkaniques est mis à disposition selon les termes de la Licence Creative Commons Attribution - Pas d'Utilisation Commerciale 4.0 International. 


\title{
Yugoslav female partisans in World War II
}

\author{
Les femmes partisanes yougoslaves pendant la Seconde Guerre mondiale
}

Ivana Pantelić

\section{AUTHOR'S NOTE}

This text is written within the project Serbian society in the Yugoslav state in the 20th century: between democracy and dictatorship (No. 177016) of the Ministry of Education and Science of the Republic of Serbia.

This paper deals with female partisans' role and integration with in wartime society in Yugoslavia. Women public engagement, during the war, was very important for process of emancipation in post war Yugoslavia. This was first time that women joined military forces, especially combat unites. We shall present what were their motives to join partisan movement and which were their positions in the Communist Party of Yugoslavia and in People's Liberation Army (PLA). We shall also discuss about official documents that were published during the war and are immediate related to the emancipation factors. A distinctive part of this paper will include description and analysis of establishment and first activities of Women's Antifascists Front of Yugoslavia (WAFY). We shall also try to compare female partisans' engagement with the Greek and Soviet women activities in guerilla warfare during the WWII. Our research was based on unpublished and published documents of the resistance movement, wartime press as well as on the memoirs of female partisan's.

\section{Women in the Partisan's units}

In addition to huge losses and destruction, the world wars have brought substantial social change. During the First World War in Britain and in France, due to their contribution to the home front, women acquired a significant role by replacing men in 
industry and in various other jobs, a role that gained prominence during the Second World War, both on the home front and in the military operations. In the early years of the war, classic fronts had yet not been established and, as the opposition had not been quelled in the region of the German Reich and its satellites and occupied countries, women were given an important place in the guerrilla units and resistance movements.

In addition to the Soviet partisan units that from 1941 sprang up over the large territories under the German occupation and the great French resistance, the two largest guerrilla forces in Europe operated in the Balkans: the communist movement in Yugoslavia and The Greek People's Liberation Army (ELAS). The Yugoslav Partisans (People's Liberation Army of Yugoslavia or Narodnooslobodilačka vojska Jugoslavije NOVJ) and the ELAS were not only fighting for liberation from the occupier, but they also began the Communist Revolution. In addition to establishing the socialist system following the model of the Soviet Republic, these movements wanted to encourage a radical change in social relations. One goal was to legalize gender equality and to accelerate the emancipation of women. Partisan warfare was the first opportunity to set an important stage in this process. Just as the National Liberation Committees (Narodnooslobodilacki odbori) throughout the liberated territories established the new government, during the war female partisans (partizanke) gained their role in the new society, the role that would, in the ideal new society after the war, be secured for the entire female gender. The term partizanke has been most often used in reference to female fighters and nurses. The typical representation of the female partisans, in the post-war Yugoslav society is a young, armed, girl who fights and heals the wounds. ${ }^{1}$ Female partisans have become a kind of political and social vanguard among women.

The Partisan uprising began three months after the April War (invasion of Yugoslavia, 6-17 April 1941) and the subsequent disintegration of the Kingdom of Yugoslavia. Having had a hostile attitude toward the occupying forces, the Communist Party called for a popular uprising on 4 July 1941, two weeks after German assault on the Soviet Union (June 22). By the end of 1941, People's Liberation Army of Yugoslavia had accepted a new concept of warfare: the establishment of highly mobile proletarian brigades (proleterska brigada) and, later, the proletarian divisions (proleterska divizija) in which women constituted a significant part of the medical corps. After the April War of 1941 and the occupation and division of Yugoslavia, the new communist guerrillas (the Partisans) organized themselves throughout the territory of the former state. Unlike other antifascist and collaborationist movements, the partisan movement advocated the complete emancipation of women in post-war socialist Yugoslavia. Since the guerrillas, from the beginning, presented themselves as the embryo of a new state, women straightaway had an opportunity to play a prominent role in shaping of the revolutionary authorities and a secure place in the partisan revolutionary army.

The phenomena of partizanke as in Yugoslavia was not unique. However, it should be noted that despite the different social conditions, to a lesser or greater extent specific for most of Europe, as well as the specifics of Yugoslav society and its contradictions during the interwar years, the phenomena of women's mass military engagement presented a major and unexpected shift. When it comes to social analysis of the partisan revolutionary army, we should bear in mind that, before the war, barely a quarter of the Yugoslav population lived in cities. Although a woman had a subordinate role in this rural world, several factors significantly affected her entry into the revolutionary partisan army. The weapon development and the nature of warfare made 
women, as much as (un)educated men, a significant potential. Finally, the rapid development of cities, as well as the arrival of many female teachers into villages after 1918, ensured that such ideas were not as inconceivable as they were before.

As for the ideology, program and staffing, the Partizans and Yugoslav People's Liberation Army relied on the Communist Party of Yugoslavia (Komunistička partija Jugoslavije - KPJ). The Party publicly advocated legal and practical equality of the sexes. However, until the end of the war, women's participation in the Communist Party was merely symbolic. However, by May 1941 women members of the Communist Party, the Young Communist League of Yugoslavia (Savez komunističke omladine Jugoslavije - SKOJ) and female activists of pre-war Women's movement joined the partisan movement. ${ }^{2}$ According to data presented by Stanko Mladenović, participation of women in the first partisan units varied from $2 \%$ to $20 \%$. So the First Proletarian Brigade (Prva proleterska brigada) at the time of its formation had 67 women, in the Second Proletarian Brigade (Druga proleterska brigada) there were 46 women, most of whom were medical workers, while in the Fourth Proletarian Brigade (Četvrta proleterska brigada), among 1,082 fighters 200 were women. ${ }^{3}$ According to official statistics, by the end of war, about 100,000 women entered into the ranks of the People's Liberation Army of Yugoslavia. Barbara Wiesinger says that this figure is exaggerated and that women accounted for $5-10 \%$ of the partisan units. It is estimated that during the war 25,000 of them were killed or died and 40,000 were wounded. Neda Bozinović, judging by incomplete data, estimated that only in Serbia more than 1,500 women were executed. ${ }^{4}$ Most of them served as medical staff, although they were also present in all combat units. Women doctors and nurses with a history of leftist activism had every reason to disappear from the occupied towns into the forest. Consequently, 173 women doctors and an estimated 10,000 trained nurses volunteered for service in the National Liberation Army. ${ }^{5}$ Some authors, such as Neda Bozinović, argue that the leadership of the Communist Party at first hesitated whether to allow the entry of women into the combat units. During the mass uprising of the 1941 in Serbia, the partisan units included few women. In early 1942, however, the partisan leadership decided to make combat roles officially available to women. A letter by Tito, written in February 1942, explained this to his associates: "Since ever more women demand to join the [partisan] units, we have decided to accept them ... not only as nurses, but also as fighters. It would be a real disgrace for us to make it impossible for women to fight with a weapon in hand for national liberation." ${ }^{16}$ The exceptions were pre-war communists who took active part in organizing the first insurgent units. During the war women were not able to progress to the higher command or political positions in the military. Also, there were no women in the top ranks of the Communist Party leadership (Politburo). During the war, about 2,000 women have been promoted to officer ranks in the Yugoslav People's Liberation Army. The Order of National Hero was awarded to 1,241 men and 93 women. ${ }^{7}$ Among national heroes there were $7.03 \%$ woman of total awarded, and they accounted for around $13 \%$ of combatants in the war. By comparison, in Greece, equally patriarchal society, where the war for liberation turned into a civil war, female partizans accounted for $30 \%$ of the wartime composition of the Democratic Army of Greece and $70 \%$ of medical and auxiliary staff. ${ }^{8}$ In the Soviet Union where women enjoyed equality officially since 1917, number of women serving in the Red Army during the war reached 800,000. Although one in four was awarded, only 89 of them received the Hero of the Soviet Union medal (during Second World War, the Hero of the Soviet Union was awarded to 11,635 people). ${ }^{9}$ The Second World War in Britain saw women actively 
participating in the military. In June 1945 Women's Auxiliary Territorial Service accounted for $6.13 \%$ of the military, Women's Royal Naval Service $8.42 \%$ of the entire Navy, while Women's Auxiliary Air Force accounted for $13.87 \%^{10}$

At the beginning, the question of women's equality was not emphasized as one of the goals of the National Liberation War (Narodnoslobodilacka borba). Although in the defining documents for the establishment of new authorities (National Liberation Committees) it was not particularly stressed that women will get active and passive voting rights and there was no formal plan for their entry into the partisan units, women still enjoyed these rights. ${ }^{11}$ From the beginning of the war, women's committees were organized at different levels (village, local, county), with the task to assist the partisan units and the new government, to organize ambulance training and to participate in the political education of women. It can be said that the first documents in which the partisan government anticipated full equality for women were published in the eastern Bosnian town Foča in February 1942. Two documents entitled Duties and Organization of National Liberation Committees and Explanations and Instructions to the National Liberation Committees in the Liberated Areas established the right of women to vote and to be elected to the organs of revolutionary authority. ${ }^{12}$

Women were indeed in symbolic numbers chosen to the highest institutions of the Partisan state. Thus, at the First Congress of the Antifascist Council of the People's Liberation of Yugoslavia (Antifašističko Veće Narodnog Oslobođenja Jugoslavije -AVNoJ), in the northern Bosnian town Bihać on 26 November 1942, the only woman delegate was Kata Pejnović. ${ }^{13}$ Only 11 women attended the Second Congress, held on 21-29 November 1943. ${ }^{14}$ In the Second Congress of the AVNOJ, women accounted for just over $4 \%$ of the lawmakers. ${ }^{15}$ On that occasion the new Yugoslav government named the National Committee of Liberation of Yugoslavia (Nacionalni komitet oslobodenja Jugoslavije - NKOJ) was elected. The National Committee of Liberation of Yugoslavia had 17 members, but no women among them. The presidency of the AVNOJ had a total of 63 members, among which were only two women (3\%). ${ }^{16}$

\section{The Women's Antifascist Front of Yugoslavia}

A body that gave an opportunity to women to self-organize politically and through this to activate as many women as possible was the Women's Antifascist Front of Yugoslavia (Antifašistički front žena Jugoslavije - AFŽJ). AFŽJ held its first conference in Bosanski Petrovac (northwestern Bosnia) on 5-7 December 1942. Previously, female partizans had activities in their units and in the regions they fought. The First National Conference of the AFŽJ was the first opportunity for women to coordinate their activities at the Yugoslav level. Delegates at the Conference were leaders of the Communist Party, an activist of pre-war Women's movement, young women that became active during the war, and members of the partisan units. The Conference brought together 166 female delegates, ${ }^{17}$ the session lasted for three days. The AFŽ's most important objective was to provide support system for the Peoples Liberation Army by mobilizing women's labour. The other objectives of this Conference were to connect women from different territories of occupied Yugoslavia, the emancipation of women through eliminating literacy among women, political education and equal participation in the Partisan war activities. Women collected food, clothing, they also sewed uniforms, knitted sweaters and socks, provided medical supplies. Many key 
services for the army were provided by the AFŽ. In addition, the AFŽ made significant contribution to the medical corps as they mobilized and trained women to serve as Partisan nurses. ${ }^{18}$ The social and humanitarian work was organizations prominent activities. The AFŽ run orphanages and children's homes in the liberated zones and provided aid and care to the families and widows of Partisan solders. The organization helped accommodated the exiled Partisan families and numerous refugees that followed the units on the move. ${ }^{19}$ In order to achieve all of these objectives AFŽ soon took on many responsibilities that, in the condition of regular warfare, would be associated with the home-front and coordinated by the state. ${ }^{20}$ Despite all humanitarian activities ${ }^{A F Z ̌ ~}$ did not pass a milestone in the program objectives for the emancipation of women in the partisan movement, or in the unfolding socialist state. However, on that occasion the first mass Yugoslav women's political organization was created which will play a huge role in post-war history of women's emancipation.

Josip Broz Tito attended the Conference, he stressed the importance of the presence of women in combat and underlined their crucial place in the background:

Female comrades! It is clear that a huge share of the burden in this struggle falls on women - both on the home front and so often in the combat. Your sons, fathers and brothers are, of course, the soldiers on the battlefield, and you are also an important background factor. Everything that our army is capable of doing today is also a credit to our heroic women of Yugoslavia. The fight that we conduct requires tremendous sacrifices and the brunt of those sacrifices falls on our mothers and daughters who are losing their loved ones." ${ }^{21}$ But finished speech in less patriarchal, traditional sense: "I can say that in this struggle, by their heroism and their endurance, women have been at the forefront. The peoples of Yugoslavia should feel honoured to have such daughters. I am proud to be the leader of an army that includes an enormous number of women..$^{22}$

Spasenija Cana Babović, member of the CPY's Central Committee, who after the war became the president of the Central Committee of the AFŽJ, devoted her speech to the issues of the organization. Based on this speech, it is clear that one of the most important goals of the First National Conference of the AFŽJ was to boost women's participation in the war efforts. ${ }^{23}$

AFŽ mostly gathered older, married females over the age of 30. This was part of the Party policy. As the most numerous and devoted female partisans were very young girls in their early twenties and they already were involved in Party's activities, CPY's leaders supported the idea that AFŽ should target older women, uninvolved in the movement. As Jelena Batinić in her PhD theses noticed: "The archetypal AFŽ member was the very presiding over the organization's Central Council, Kata Pejnović, a serb from Lika, who had lost her three sons and husband to the Ustasha terror at the beginning of the war." But the AFŽ leadership, during and after the WWII, on the state and federal levels, was not typical profile. All of them, with the exception of Kata Pejnović, were educated, pre-war Party members or communist youth activists. Most prominent among them were Mitra Mitrović, a pre-war CPY activist and graduate of University of Belgrade, very active in the Youth Section of the Women's Movement in Kingdom of Yugoslavia, Vida Tomšič, lawyer from the University of Ljubljana and prewar CPY member, Spasenija Cana - Babović, the CPY's Central Committee member and professionally politically trained in Serbia and Moscow, Vanda Novosel, activist and editor of the pre-war women's journal Ženski svijet in Croatia. 
About activities of the AFŽ during the war, but also about the patriarchal family relations, and attempts to break them up writes female partisan Nevenka Petrić. Although she considered that the AFŽ had no influence on her emancipation, she says:

To be able to organize women you need to know that they have no say. If her husband says that she must go, she will come to a meeting. If he says that he doesn't agree, then she can't come. To found the AFŽ in a village, there must be a National Liberation Committee, which I come and set up. They heard about me from peasants in other villages and they say: that little one will come, so when the 'little one' comes, they set up a National Liberation Committee. In addition to its political activities, the Committee collects food for hospitals and military units. Politics has always been the main thing! It was emphasized that the sessions were dedicated to women, but that men may come if they wish and they came in smaller numbers. Women generally came if they were widows or those who wore pants in their house. Some would come with their husbands, but with their prior consent. At the meetings the participants would say that women have never had any rights in society, although they contribute to the household as much as the male members. The aim was political, the French Revolution would be mentioned, its ideas, the Marxist movement, and there was talk about Marx. Women understand that they now have no rights, and from now on, they will like to have them. The goal was to raise awareness among them, so that woman can accept herself as a person capable of making decisions in the household. Women give birth to children, run the household, and finally they are labourers in the field and work with the livestock. Women have participated in these meetings by talking about their lives. Many wanted me to be their daughter-in-law because they liked me. For these reasons, many told me in what military units their sons were." ${ }^{24}$

During the war the Antifascist Council of Women began to build organizations all around the country. By the end of 1943, throughout Serbia, district, county and municipal committees were created.

It should be noted that at the beginning of the 1944 a women's Ravna Gora organization was formed under the name the Yugoslav Women's Ravna Gora Organization (Jugoslvemnska organizacija Ravnogorki - JUORA). The task of this organization was to build a network of clubs and associations, with the help of the operational units of the Yugoslav Army in the Fatherland (Jugoslovenska vojska u otadžbini - JVO or Četnički pokret). In addition to setting up medical units, JUORA members had the task to raise national awareness among adults and children, and one of the most important was the "sister" help to the soldiers as well as their "brave conduct in the face of the enemy". ${ }^{25}$ We can conclude that unlike the AFŽ, which undoubtedly had similar tasks when it come to activities in the war but also devoted its efforts to raising women's literacy and providing cultural and political training programs, the work of the JOURA was confined exclusively to helping fighters (men) and to their role of good mothers and citizens. Modelled on the character of national heroine from the 14th century (Kosovka devojka) their role was even symbolically based on the principle of "women as an unequal helper".

Barbara Wiesinger concludes that women in the framework of the People's Liberation Army of Yugoslavia constituted a social object, they were deprived of personal initiative, and their roles defined by the military and political leaders - men. ${ }^{26}$ In contrast, the Party historiography and some later authors considered that partizanke were led into the war by their high self-awareness and their desire for the emancipation. ${ }^{27}$ Our interviewee Vera Đukic-Plavsić, who was herself a combatant, has written about women's participation in the partisan movement in following way: 
"Their heroism was startling, their quest for freedom could not be broken neither by fear nor by death, hunger or bullets. Taking part in military operations with the strength of their youth, female comrades of Forth Serbian Brigade, despising the fear, gave up the love and motherhood in the constant face of death." ${ }^{28}$

Anthropologist Svetlana Slapšak, has also considered a phenomena of female partisan:

The success of the Yugoslav partisan movement was comprehensive: it provided the female workforce in the background, the female warrior force to the front, the women's labour force in rebuilding the country after the war and the women's political forces that supported the winning ideology... A woman in uniform, a woman capable of using a weapon, a woman who kills: an essential element of the engraved image of the female Partisan is fear. It does not help that women rarely reached the commanding positions, and that the military career to them was mostly closed. To her comrades, perhaps no less than to her opponents, she represented a threat of a perfectly protected and therefore independent offensive sexuality. A woman bearing arms makes her own choices... ${ }^{29}$

\section{Why? The motives of female partisans}

The motive of departure of female partisan to war speaks eloquently about their selfawareness and aspirations. Most of our interviewees today emphatically assert that they went to the Partisans motivated by the idea of the national defence from occupiers and the destruction of the "repressive regime". It can be said that our female interlocutors belonged to the minority of female partisans, who were either associated with the partisan movement, or were members of the Communist Party or the Communist Youth League before the war. However, although they considered themselves already emancipated, they joined the Party and/or were enlisted in the partisan units, joining their brothers or friends. According to their testimonies, their expectations were mainly associated with the war effort for the liberation and revolutionary change in the society. To a greater extent this was the case of enlightened and previously active female partisan. However, female partisans recruited from villages whose going to war was often the result of their circumstances, did not have any developed awareness of their position, or clear expectations of the future.

Female partisans's goals and their expectations from today's perspective are also incoherent. Danica Dana Milosavljević, later awarded the Order of National Hero, said that since childhood she wanted to be an equal, imagining that she was a soldier and a man, but reading the works of August Bebel before the war, prompted her to join the Partisans:

My parents for a long time did not have children and wanted a son. I wanted to be a son, I wanted to be a soldier. A hundred times I have run under the rainbow to become a male, she says. She joined the Partisans at the beginning of the war. At first she was a nurse in the platoon (četa) of the Third Užički Partisan Detachments, later she entered the medical corps of the First Proletarian Brigade, and by the end of the war she became a member of the Second Proletarian Brigade as a fighter and bomber: I asked to be a fighter but they did not let me. They said: How could you be a fighter? I went to the Supreme Headquarters to complain to Tito (Josip Broz Tito). There I met with another member of the Supreme Headquarters, Sreten Žujović... and he approved it. Since then I hugged my rifle and I gave it to no one. I distributed my medical supplies and told my friends who did not have respect for me: So here, bandage yourselves. I was very keen to be a fighter to prove myself and I did everything male fighters did, I didn't spare myself. And when I persisted over the first few months, they did not complain. ${ }^{30}$ 
However, most of the others, regardless of their later careers and education, cite different reasons. Those who were members of the Communist Party before the war or were considered its followers regarded their participation in the partisan movement a logical continuation in their work.

The partisan movement in Yugoslavia was the largest revolutionary army in Eastern Europe, which, among other things, advocated for women's equality. The issue of women's emancipation set in existence since the beginnings of the Communist Party of Yugoslavia as an important and, certainly, very difficult question. The fact that women, despite the aspirations of the Party to win them over, and in spite of customized organizational structure, were poorly represented in the membership of the Party and its leadership, limited the participation of women during the war. However, the massive uprising in western Serbia, Bosnia and parts of Croatia, as well as the changes in the conduct of war and a numerical strength of the generation born after the 1918, whose members did much of the fighting for the People's Liberation Army, contributed to women's more prominent role in the Communist Party. Unlike the Red Army and its partisan units, in which women previously had a distinctive role, the Yugoslav partizanke started a new page in the social history of Yugoslavia and the insurrectionary war. Although they were not equally represented in political parties and the partisan institutions of the state, partizanke were more proportionally represented in People's Liberation Army than in the most other similar armies, and won additional highest awards than female members of the Red Army. Based on our research, we concluded that the aspiration for the emancipation and the equality was not prevalent among female partisans, but they were primarily concerned with their patriotic and revolutionary motives.

\section{NOTES}

1. J. Batinić, Gender, Revolution and the War: The Mobilization of Women in the Yugoslav Partisan Resistance during World War II, PhD thesis defended in 2009, Stanford Univ. 162.

2. N. Božinović, Zensko pitanje u Srbiji u 19. i 20. veku /Womens question in Serbia in 19. at 20. century/, (Beograd: Feministicka 94, 1996), 135.

3. S. Mladenović, Spasenija Cana Babović, (Beograd: Rad , 1980) 211.

4. N. Božinović, 144; According to documents provided by the Yugoslav Commission for War Crimes, throughout Yugoslavia 282,406 women died in concentration camps. In Serbia that number is 18.708; Žene žrtve fašističkog terora, AFŽJ 141-10-50, Archive of Yugoslavia (A.J.)

5. B. Wiesinger, "... denn die Freiheit kommt nicht von alleine«. Frauen im jugoslawischen »Volksbefreiungskrieg« 1941-1945, PhD thesis defended in 2005, Salzburg; Vera Gavrilović, Ženelekari u ratovima 1876-1945 na tlu Jugoslavije (Beograd: Naučno društvo za istoriju zdravstvene kulture Jugoslavije, 1976), 53, 56-61.

6. J.B.Tito, Drugu Bevcu i Loli /To Comrades Bevc and Lola/ 23. February 1942, in Žena u Revoluciji / Woman in Revolution/ (Srajevo: Svjetlost, 1978), 62-63.

7. Women national heroes accounted for $7,03 \%$ of the total number of awards given, while they accounted for around $13 \%$ soldiers in the war, Lj. Petrović, Narodni heroji u jugoslovenskom društvu 
1942-1980. godine, Prilog istraživanju položaja boračkih elita u posleratnoj Jugoslaviji, Vojno-istorijski glasnik, no. 1, (Beograd: Vojno-istorijski institut, 2001), 131.

8. C. Pateras, Notes on the Greek Civil War (1946-1949), http://inter.kke.gr/News/2006new/2006-09civil1 (03 11 2010).

9. H. Skaida, Heroines of the Soviet Union 1941-45, (London: Osprey Publishing, 2003); P. D. McDaniel Jr, P. J. Schmitt, The Comprehensive Guide to Soviet Orders and Medals, 1997.

10. L. Noakes, Women in the British Army, War and the gentle sex, 1907-1948, (New York: Routledge 2006), 131.

11. Period rada 1941-1945, AFŽJ 141-10-50, A. J.

12. Ibid.

13. Žene članovi AVNOJ, Žena danas /Woman today/, no. 35, October 1945, 10. However, in the AFŽJ document about war activities of this organization it is quoted that the female delegates were Spasenija Cana Babović i Kata Pejnović. Period rada 1941-1945, AFŽJ 141-10-50, A. J.

14. S. Nešović (ed.), Drugo zasedanje Antifašističkog veća narodnog oslobođenja Jugoslavije 1943-1953, Beograd [1953?], 190-193.

15. S. Nešović, 190-193; Neda Božinović calculated that women accounted for 3,7\% of delegates of Second National Conference AVNOJ; N. Božinović, 150.

16. S. Nešović, 189.

17. AFŽJ 141-14-74, A. J.

18. J. Batinić, 126.

19. Ibid.

20. B. Jancar-Webster, Women and Revolution in Yugoslavia, (Denver: Arden Press 1990), 139.

21. Josip Broz Tito, Govor na prvoj zemaljskoj konferenciji AFŽ-a, Žena u revoluciji, (Sarajevo: Svjetlost 1978), 81-82.

22. Ibid.

23. Za učvršćenje organizacije - prema usmenom referatu Cane Babović, AFŽJ 141-14-75, A. J.

24. Interview with Nevenka Petrić-Lalić, 30 July 2007.

25. B. B. Dimitrijević, Žene ravnogorskog sela 1943-1944, in L. Perović (ed.) Srbija u modernizacijskim procesima XIX $i$ XX veka: položaj žene kao merilo modernizacije, 2 ( Beograd: Institut za noviju istoriju Srbiije, 1998), 359.

26. B. Wiesinger, 219.

27. "Regardless of their function, level of education, social background, they (partizanke) liberated themselves from prejudices of their subordinate social position in battle, in the communal life and constant work on their experiences", N. Božinović, 143.

28. V. Đukić-Plavšić, Sećanja na Drugi svetski rat /Remembering Second Wrld War/, in possession of Ivana Pantelić.

29. Svetlana Slapšak, Ženske ikone XX veka /20th Century Women's Icons/, Beograd 2001, 208.

30. Interview with Dana Milosavljević, conducted 19 September 2007.

\section{ABSTRACTS}

Women public engagement, during the war, was very important for process of emancipation in post war Yugoslavia. This was first time that women joined military forces, especially combat unites. In addition to the Soviet partisan units that from 1941 sprang up over the large territories 
under the German occupation and the great French resistance, the two largest guerrilla forces in Europe operated in the Balkans: the communist movement in Yugoslavia and The Greek People's Liberation Army (ELAS). The Yugoslav Partisans and the ELAS were not only fighting for liberation from the occupier, but they also began the Communist Revolution. In addition to establishing the socialist system following the model of the Soviet Republic, one goal was to legalize gender equality and to accelerate the emancipation of women. During the war female partisans (partizanke) gained their role in the new society, the role that would, in the ideal new society after the war, be secured for the entire female gender. By the end of 1941, People's Liberation Army of Yugoslavia had accepted a new concept of warfare: the establishment of highly mobile proletarian brigades in which women constituted a significant part of the medical corps. In early 1942, however, the partisan leadership decided to make combat roles officially available to women. During the war women were not able to progress to the higher command or political positions in the military. Also, there were no women in the top ranks of the Communist Party leadership (Politburo). Women were indeed in symbolic numbers chosen to the highest institutions of the Partisan state. A body that gave an opportunity to women to self-organize politically and through this to activate as many women as possible was the Women's Antifascist Front of Yugoslavia (Antifašistički front žena Jugoslavije - AFŽJ). AFŽJ held its first conference in Bosanski Petrovac (northwestern Bosnia) on 5-7 December 1942.

The fact that women, despite the aspirations of the Party to win them over, and in spite of customized organizational structure, were poorly represented in the membership of the Party and its leadership, limited the participation of women during the war. Although they were not equally represented in political parties and the partisan institutions of the state, partizanke were more proportionally represented in People's Liberation Army than in the most other similar armies, and won more of the highest awards than female members of the Red Army.

L'engagement public des femmes pendant la Guerre a été très important pour le processus de leur émancipation dans la Yougoslavie de l'après-guerre. Pour la première fois des femmes rejoignirent les forces armées, spécialement des unités de combat. En plus des unités soviétiques de partisans qui, à partir de 1941, surgirent sur de larges territoires sous occupation allemande et de l'importante résistance française, les deux plus grandes forces de guérillas qui ont opéré en Europe furent le mouvement communiste en Yougoslavie et l'Armée de Libération populaire grecque (ELAS). Les Partisans yougoslaves et l'ELAS ne luttaient pas seulement contre l'occupant, ils commençaient aussi une révolution communiste. En plus d'établir un système socialiste selon le modèle soviétique, l'un de leurs buts était de proclamer l'égalité des sexes et d'accélérer l'émancipation des femmes. Les femmes partisanes (Partizanke) obtinrent un rôle dans la société, rôle qui serait dans la société idéale nouvelle de l'après-guerre, assuré à toutes les femmes. À la fin de 1941, l'Armée populaire de Libération Yougoslave avait adopté une nouvelle tactique : la création de brigades prolétariennes très mobiles dans lesquelles les femmes constituaient une part importante du personnel médical. Au début de 1942 cependant, les dirigeants des partisans acceptèrent de donner des postes de combat aux femmes. Pendant la guerre, les femmes n'ont pu atteindre des postes élevés dans l'armée ni en politique. Il n'y eut pas non plus de femmes dans les postes les plus élevés de la hiérarchie du Parti communiste (Politburo). Les femmes étaient choisies pour figurer symboliquement dans les hautes institutions de l'État partisan. Mais le Front antifasciste des Femmes de Yougoslavie qui tint sa première Conférence à Bosanski Petrovac (NW de la Bosnie) les 5-7 décembre 1942 leur a donné la possibilité de s'auto-organiser politiquement et d'éveiller ainsi le plus grand nombre de femmes.

Le fait que des femmes, malgré le désir du Parti de les attirer à lui, et en dépit de structures d'organisation personnalisées, ont été pauvrement représentées parmi les membres du Parti et sa direction limita la participation féminine pendant la Guerre. Mais bien qu'inégalement représentées dans les partis politiques et les institutions partisanes de l'État, les partizanke ont 
été proportionnellement plus représentées dans l'Armée de Libération populaire que dans la plupart des armées similaires et ont gagné plus de médailles et récompenses élevées que les femmes de l'Armée rouge.

\section{INDEX}

Geographical index: Yougoslavie

Mots-clés: AFŽJ, femmes-partisans, femmes au front, NOVJ, femmes dans le Parti Communiste, KPJ, NKOJ, émancipation des femmes, SKOJ, ELAS

motsclestr Kadın-partizan, Savaşında Kadın, Komünist Parti kadınları, Kadınların güçlendirilmesi, Yugoslavya, Ilk Dünya Savaşı, Tarih, Kadın Tarihi

Keywords: women-partisan, women on the front, women in the Communist Party, women emancipation, Second World War, women history

motsclesmk ЖЕНИ ОТПОРНИ, ЖЕНИТЕ НА ПРЕДНАТА, ЖЕНИТЕ ВО КОМУНИСТИЧКАТА ПАРТИЈА, ЗАЈАКНУВАњЕ НА ЖЕНИТЕМ, ЈУГОСЛАВИЈА, ВТОРАТА СВЕТСКА ВОЈНА, ИСТОРИЈА, ИСТОРИЈАТА НА ЖЕНИТЕ

Subjects: Histoire, Histoire des femmes

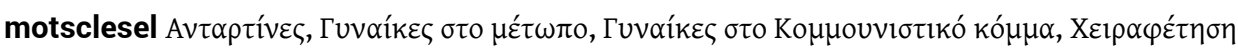

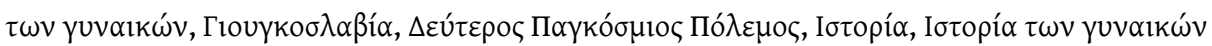

Chronological index: guerre mondiale (1939-1945) 